\title{
Inhibition of insulin-specific autoreactive T-cells by sulphatide which is variably expressed in beta cells
}

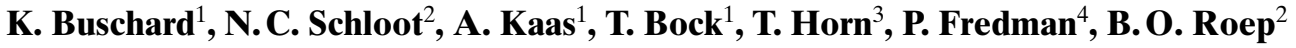 \\ ${ }^{1}$ Bartholin Instituttet, Kommunehospitalet, Copenhagen, Denmark \\ ${ }^{2}$ Department of Immunohaematology and Blood Bank, University Hospital, Leiden, The Netherlands \\ ${ }^{3}$ Department of Pathology, Herlev Hospital, University of Copenhagen, Denmark \\ ${ }^{4}$ Department of Clinical Neuroscience, Section of Neurochemistry, Mölndals Hospital, University of Göteborg, Sweden
}

\section{Abstract}

Aims/hypothesis. Sulphatide and insulin are present in the secretory granules and at the surface of beta cells in islets of Langerhans. Insulin autoantibodies and T-cell reactivity against insulin exist during the development of Type I (insulin-dependent) diabetes during which active beta cells may be more vulnerable than passive. Our aims were to examine the presence of sulphatide in active and passive beta cells and to clarify whether sulphatide influences the direct autoimmunity against insulin.

Methods. We incubated rat islets in $2.8,11.0$ or $20.0 \mathrm{mmol} / \mathrm{l}$ glucose for $24 \mathrm{~h}$ and did an electron microscopic evaluation after labelling with a specific anti-sulphatide monoclonal antibody. The reactivity of an insulin-specific T-cell clone isolated from a patient with Type I diabetes, was examined using insulin or insulin B-chain (B11-27) peptide incubated together with sulphatide.

Results. We detected lower amounts of sulphatide per insulin secretory granule in active compared with passive beta cells $(p=0.003)$. The presence of sulphatide in vitro at doses of $43-8.3 \mu \mathrm{mol} / 1 \mathrm{resulted}$ in greatly reduced proliferation (median $3.4 \%$ of control value, $p=0.0004$ ) of the insulin-specific Tcell clone. No inhibition was found using the precursor of sulphatide, galactosylceramide, or GM1. Sulphatide did not reduce non-aspecific proliferation (induced by phorbol myristate acetate plus anti-CD3) or specific proliferation induced by insulin peptide.

Conclusion/interpretation. These results imply that sulphatide possibly affect processing of the insulin molecule. Sulphatide which has been reported to interfere with phagosome-lysosome fusion, conceivably interacts with insulin. We hypothesize a (patho)physiological role of sulphatide, variably expressed in beta cells, by reducing the antigenicity of insulin. [Diabetologia (1999) 42: 1212-1218]

Keywords Type I diabetes mellitus, insulin, autoreactive T-cells, sulphatide, beta cells.
Sulphatide (3'-sulphogalactosylceramide) is a glycolipid biosynthezised from ceramide originating from sphingosine, to which a galactose substituted with sulphate is attached. Galactosylceramide (galcer) is the direct precursor without sulphate. Sulphatide is known to be present in both the central and pe-

Received: 25 March 1999 and in revised form:1 June 1999

Corresponding author: K. Buschard, MD, Bartholin Instituttet, Kommunehospitalet, DK-1399 Copenhagen K, Denmark Abbreviations: Gal-cer, galactosylceramide; PMA, phorbol myristate acetate. ripheral nervous system as well as in kidney tubules and in islets of Langerhans $[1,2]$. The physiological role of sulphatide is not fully known but an involvement in cation transport has been suggested as well as in cell-to-cell interactions and in intracellular events [3]. In nerves sulphatide is implicated in myelination [4].

Several possible patho-physiological functions of sulphatide have been described; sulphatide may play a part in adhesion as being a ligand to CD62/P-selectin [5]. Also, sulphatide has been shown to be a modulator of cytokine production from neutrophils [6], T-cells [7] and monocytes [7]. Sulphatide autoanti- 
bodies have been shown in association with diseases affecting organs where sulphatide is localized. Considering the nervous system such antibodies have been found in Guillain-Barré syndrome [8], in multiple sclerosis [9] and in peripheral nerve disease in AIDS [10]; in the islets, sulphatide antibodies are expressed in Type I (insulin-dependent) diabetes mellitus.

In islet cells, sulphatide is present in the secretory granules [2] together with insulin, which is an autoantigen in Type I diabetes giving rise to both anti-insulin autoantibodies [12] and T-cell autoreactivity against insulin [13]. The function of sulphatide in the granules is not known but its physical and chemical properties possibly imply that sulphatide is involved in vesicle transport, vesicle $\mathrm{pH}$ regulation [3], and/or the exocytotic process of insulin secretion. Increased beta-cell activity has been suggested as a diabetogenic risk factor [14] and beta cells at rest seem less likely to be attacked by the immune system as illustrated by prophylactic insulin treatment [15-17]; this possibly, however, also acts by tolerating for the insulin autoantigen [18].

The aim of our study was to compare the presence of sulphatide in secretory granules in active and passive beta cells and to explain whether sulphatide plays any part in the direct autoimmunity against insulin.

\section{Materials and methods}

Islet origin and preparation. Islet tissue was obtained from 32,8 to 10 -week-old, male Lewis rats purchased from Møllegaard (Ll. Skensved, Denmark). The islets were isolated as described previously using a collagenase method [19]. Thereafter, the islets were divided into three portions and incubated at 2.8, 11.0 and $20.0 \mathrm{mmol} / \mathrm{l}$ glucose, respectively, in RPMI 1640 (Gibco, Paisley, UK) with $10 \%$ fetal calf serum and $1 \%$ PenicillinStreptomycin (10000 IU/ml-10000 $\mu \mathrm{g} / \mathrm{ml}$, Gibco) for $24 \mathrm{~h}$ at $37^{\circ} \mathrm{C}$. Beta cells in isolated intact islets are known to respond to increasing glucose concentration with increasing insulin secretion [20]. The Principles of laboratory animal care (NIH publication no. 85-23, revised 1985) were followed.

Electron microscopy. Immediately after the incubation, the islets were fixed for $1 \mathrm{~h} / 30 \mathrm{~min}$ in a mixture of $2.5 \%$ paraformaldehyde and $0.2 \%$ glutaraldehyde. After washing in cacodylate buffer, $\mathrm{pH} 7.3$, and dehydration in $70 \%$ alcohol, specimens were embedded in LR-white (Bio-Rad, Watford, UK). Ultrasections were incubated for $2 \mathrm{~h}$ at $20^{\circ} \mathrm{C}$ with the monoclonal antibody, Sulph I [21], diluted 1:75. Sulph I is specifically directed against sulphatide [21]. The concentration of the primary antibody was based on dilution experiments showing no background labelling. After incubation for $1 \mathrm{~h}$ with a rabbit anti-mouse immunoglobulin (F261, Dako, Glostrup, Denmark) diluted 1:100 and absorbed with rat serum, sections were incubated for $1 \mathrm{~h}$ with goat anti-rabbit immunoglobulin conjugated with colloidal gold $(10 \mathrm{~nm}$, British Biocell, Cardiff, UK) diluted 1:100. Specimens were after washings postfixed in $2 \%$ glutaraldehyde for $10 \mathrm{~min}$ and stained with uranyl acetate/ lead citrate before examination in a Philips 208 electron microscope. For each experiment, controls were prepared by omit- ting the primary antibody as were sections treated with an irrelevant primary antibody. These controls yielded the expected negative results.

We did four independent experiments each using eight rats with isolation of islets and incubation with low, medium and high glucose concentrations. From each experiment photographs were taken of four different motifs of beta cells from four different islets, altogether giving 192 photographs with a magnification of 30000 each showing an area of $5100 \times 6900$ $\mathrm{nm}$ of beta cells. The photographs were evaluated blindly. Two photographs were excluded due to poor quality. All staining dots in each photograph were counted and localized either to the secretory granules or to cytosol. Also, the actual number of secretory granules was determined on each photograph. The four experiments gave consistent results.

T-cell proliferation assay. The T-cell proliferation assay was done as described previously [22] Briefly, $10^{4} \mathrm{~T}$-cells and $5 \times 10^{4}$ irradiated (40 Gy) HLA-matched mononuclear cells (antigen-presenting cells) were cultured in 96-well flat bottom microtitre plates (Greiner, Nürtingen, Germany). The cells were cultured in triplicate in the presence of $43,8.6,4.3$ or $0.9 \mu \mathrm{mol} / 1$ sulphatide alone or together with 4.3 or $0.9 \mu \mathrm{mol} / 1$ insulin for 3 days at $37^{\circ} \mathrm{C}$ in a humidified $5 \% \mathrm{CO}_{2}-95 \%$ air mixture. We added $\left[{ }^{3} \mathrm{H}\right]$ thymidine (NEN DuPont, Boston, Mass., USA) in $50 \mu \mathrm{l}$ RPMI 1640 at $20 \mathrm{mmol}$ HEPES (Gibco) 18 hours before termination of the culture. The samples were collected on glass fibre filters and $\left[{ }^{3} \mathrm{H}\right]$ thymidine incorporation was determined by liquid scintillation counting. We investigated two T-cell clones; a T-cell clone responding to insulin [23] (see below) and a T-cell clone responding to insulin secretory granule proteins [22]. As antigens we used; human Actrapid $100 \mathrm{U} \mathrm{ml}^{-1}$ (Novo Nordisk, Copenhagen, Denmark), synthetic peptide of amino acid 11-27 insulin B-chain [23] and RINm5 beta-cell insulinoma membranes [22], respectively. As stimuli we used; sulphatide, galactosylceramide (gal-cer) and ganglioside GM1 (see below). For non-specific stimulation we used phorbol myristate acetate (PMA) (1 ng/ml, Sigma, Zwijndrecht, The Netherlands) together with anti-CD3 (100 ng/ml OKT3, Ortho, Raritan, N. Y., USA).

Generation of insulin-specific T-cell clone. The human insulinspecific T-cell clone used in the study was derived from peripheral blood of a newly diagnosed patient with Type I diabetes and is described in detail elsewhere [23]. The peptide recognized by the clone was mapped to the insulin B-chain (B11-27). Functionally, the human insulin-specific $\mathrm{CD}^{+} \mathrm{T}$ cells had a Th $1 / 0-$ like cytokine profile and were restricted by HLA-DR16.

Preparation of glycolipids. The following glycolipids were used; 3'-sulphogalactosylceramide (sulphatide), galactosylceramide (gal-cer) and ganglioside GM1 (Fig.1). All three molecules have an amphophilic character with a hydrophilic sugar chain and a hydrophobic part consisting of ceramide, i.e. sphingosine and fatty acid. Gal-cer represents a molecule that differs from sulphatide by the lack of a negatively charged sulphate group. The GM1 ganglioside has a negative charge like sulphatide but in this case expressed by sialic acid. All the glycolipids were isolated from pig brain as described earlier [24] and their structures analysed by fast atom bombardment mass spectrometry [25]. Before use the glycolipids were prepared as follows. Stock solutions of each glycolipid were made in chloroform/methanol/water $(60: 30: 4.5 \mathrm{v} / \mathrm{v} / \mathrm{v})$ in concentrations of $1 \mathrm{mg} / \mathrm{ml}$; the tube was sealed and after $1 \mathrm{~h}$ at room temperature the solution was kept in a refrigerator. The desired amount of $\mu \mathrm{l}$ (nmol of glycolipid) was transferred to 

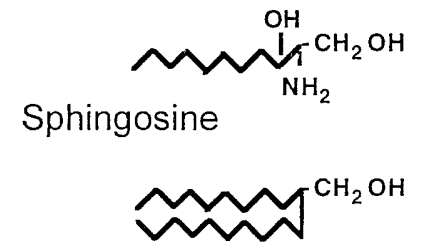

Ceramide

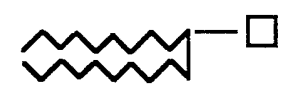

Gal-cer

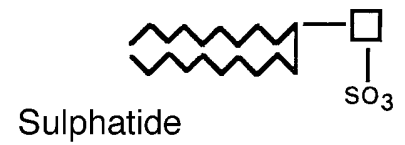

Sulphatide

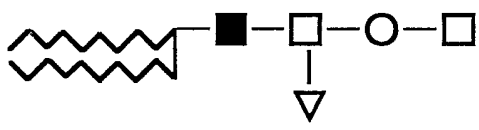

GM1

Fig. 1. Schematic drawing of glycolipids and related molecules discussed in the text. $m$ lines indicate carbon chains, $\square$ galactose, $\square$ glucose, $\bigcirc$ galactosamine, $\nabla N$-acetylneuraminic acid (sialic acid)

glass tubes and evaporated at room temperature overnight. The dried glycolipids were re-dissolved in PBS, pH 7.1 and sonicated for $20 \mathrm{~s}$ using a Branson sonicator (Danbury, Conn., USA). Immediately after this insulin was added. After 3-5 days at $4{ }^{\circ} \mathrm{C}$ the solutions were used.

Dynamic light scattering analyses. Samples of sulphatide, galcer or GM1 with or without insulin prepared as described above, were analysed by dynamic light scattering using a Zetasizer 5000 (Malvern Instruments, Malvern, UK). Particles of a diameter less than $10 \mathrm{~nm}$ were not detectable. In one experiment the samples were examined both before and after vigorously vortexing $30 \mathrm{~s}$ at $2500 \mathrm{rpm}$ using a MS1 Minishaker (IKA-Works, Wilmington, N.C., USA).

Statistics. T-cell proliferation data are presented as means \pm SD. The significance of difference was evaluated using unpaired Student's $t$ test (significant level set at 0.05).

\section{Results}

Electron microscopy studies. The results of the electron microscopy studies are presented in Table 1. Beta cells contained sulphatide in their secretory granules (Fig. 2) and active beta cells had less sulphatide staining dots than beta cells at rest. This was due to a massive decrease of staining dots in the secretory granules (from median 97 to 38) whereas there was a slight increase in sulphatide staining dots in the cytosol. The number of insulin secretory granules was reduced in the active cells but to a lesser extent than the reduction of sulphatide staining dots in the granules. Thus, the number of sulphatide staining dots per insulin granule was lower in active than in passive beta cells (median 1.03 vs $0.77, p=0.003$ ).

Insulin-specific T-cell clone. Incubation of the insulinspecific T-cell clone with sulphatide $(43 \mu \mathrm{mol} / \mathrm{l})$ and insulin $(4.3 \mu \mathrm{mol} / 1)$ resulted in greatly decreased $\mathrm{T}$ cell proliferation in seven out of nine experiments (median $3.4 \%$, range $0.9 \%-35.8 \%$ ) compared with incubation with insulin alone $(100.0 \%, p=0.0004$, Fig. 3A). When using a five times lower concentration of both sulphatide $(8.6 \mu \mathrm{mol} / \mathrm{l})$ and insulin $(0.9 \mu \mathrm{mol} /$ 1) the decrease was less pronounced $(6.7 \%)$ but still highly significant $(p=0.0005)$. When using ten times less sulphatide (i.e. equimolar range with insulin), there was no decrease measurable. Incubation of insulin with a similar high concentration of gal-cer as the highest sulphatide $(43 \mu \mathrm{mol} / \mathrm{l})$ only resulted in a slight decrease in cpm $(80.8 \%, \mathrm{NS})$, whereas gal-cer concentration of $4.3 \mu \mathrm{mol} / \mathrm{l}$ and high $(43 \mu \mathrm{mol} / \mathrm{l})$ or the lower concentrations of GM1 did not affect the T-cell response to insulin at all.

In contrast, stimulation of the T-cells with insulin B-chain peptide (B11-27) induces proliferation similar to insulin but does not require processing by the antigen presenting cells. Addition of sulphatide did not reduce the T-cell proliferation. Co-stimulation with sulphatide + insulin (Fig. 3B) did not decrease the proliferation for the low insulin concentration

Table 1. Counting results of anti-sulphatide mAb (Sulph I) labelled islet ultramicrographs

\begin{tabular}{|c|c|c|c|c|c|}
\hline \multirow{2}{*}{$\begin{array}{l}\text { Glucose concen- } \\
\text { trations }(24 \mathrm{~h})\end{array}$} & \multirow{2}{*}{$\begin{array}{l}\text { Insulin secretory } \\
\text { granules (number } \\
\text { per ultramicrograph) }\end{array}$} & \multicolumn{3}{|c|}{ Sulphatide staining dots present in: (number per ultramicrograph) } & \multirow{2}{*}{$\begin{array}{l}\text { Sulphatide dots/ } \\
\text { insulin granules }\end{array}$} \\
\hline & & insulin granules & background cytosol & all & \\
\hline $\begin{array}{l}2.8 \mathrm{mmol} / 1 \\
(n=64)\end{array}$ & $\begin{array}{l}97 \\
(78-113)\end{array}$ & $\begin{array}{l}97 \\
(68-122)\end{array}$ & $\begin{array}{l}64 \\
(47-81)\end{array}$ & $\begin{array}{l}153 \\
(136-198)\end{array}$ & $\begin{array}{l}1.03 \\
(0.74-1.24)\end{array}$ \\
\hline $\begin{array}{l}11.0 \mathrm{mmol} / 1 \\
(n=63)\end{array}$ & $\begin{array}{l}86 \\
(69-104) \\
(p=0.02)\end{array}$ & $\begin{array}{l}62 \\
(43-89) \\
(p=0.0002)\end{array}$ & $\begin{array}{l}53 \\
(38-75) \\
(N s)\end{array}$ & $\begin{array}{l}112 \\
(87-159) \\
\left(p=10^{-4}\right)\end{array}$ & $\begin{array}{l}0.71 \\
(0.51-1.03) \\
(p=0.002)\end{array}$ \\
\hline
\end{tabular}

Values are presented as median number and in brackets lower and upper quartile. $n$ indicates the number of micrographs evaluated in each glucose concentration group. The $p$ values refer to comparison between 11 and $2.8 \mathrm{mmol} / 1$ glucose concentrations or between 20 and 2.8 or $11 \mathrm{mmol} / \mathrm{l}$ glucose concentrations, respectively 

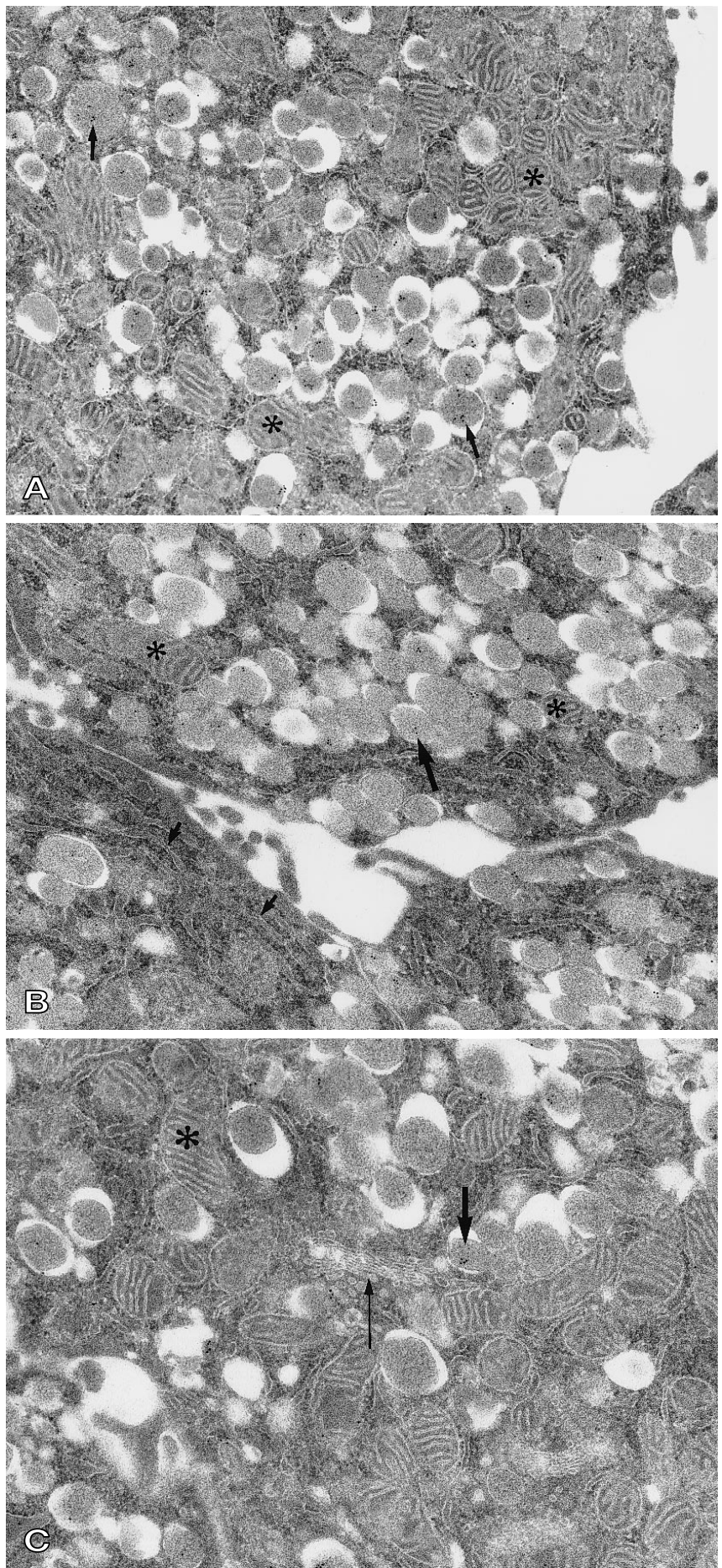

Fig. 2 A-C. Sections in original magnification $\times 12500$ of $\mathbf{A}$ an ultramicrograph of $2.8 \mathrm{mmol} / 1$ glucose incubation showing part of a beta cell with mitochondria (asterisks) and numerous secretory granules immunogold labelled for sulphatide (arrows). The surface of the cell with few microvilli is seen to the right $\mathbf{B}$ a micrograph of $11.0 \mathrm{mmol} / \mathrm{l}$ glucose incubation revealing parts of two beta cells with few microvilli on their surfaces. Profiles of rough endoplasmic reticulum (short arrows), few mitochondria (asterisks) and several secretory granules are seen in the cytoplasm. Many of the latter are unlabelled whereas some reveal immunogold labelling (long arrow) $\mathbf{C}$ a micrograph of $20.0 \mathrm{mmol} / \mathrm{l}$ glucose incubation with numerous mitochondria (asterisk), developed Golgi apparatus (thin arrow) and reduced numbers of secretory granules. Sulphatide labelling is seen (thick arrow) sample $(0.9 \mu \mathrm{mol} / \mathrm{l})$. For the high insulin concentration $(4.3 \mu \mathrm{mol} / 1)$ there was a minor, statistically nonsignificant decrease in proliferation at the 10:1 sulphatide:insulin molar ratio. Overall the changes were minimal compared with incubation with sulphatide + insulin alone which resulted in the expected reduction compared with insulin-induced T-cell proliferation $\left[\begin{array}{lll}1311 \pm 999 & (5.3 \%) & \text { vs } 24889 \pm 6091\end{array}\right.$ $(100.0 \%), p=0.002]$. In the same experiment we stimulated the T-cells non-specifically with PMA and anti-CD3 during incubation with either sulphatide + insulin or insulin alone (Fig. 3B). The presence of sulphatide in this experiment even in high concentrations did not cause significant reduction of PMA plus anti-CD3 induced T-cell proliferation.

Secretory granule-specific T-cell clone. The proliferation of the T-cell clone specific to the insulinoma membrane protein [22] when incubated with RIN cell insulinoma membranes was unaffected by simultaneous incubation with gal-cer + insulin $(82.8 \%)$, GM1 + insulin $(78.7 \%)$ or with sulphatide alone ( $80.7 \%$ of the glycolipid-free control). When simultaneous incubation was done, however, with the RIN cell membranes together with sulphatide + insulin a decrease was seen in T-cell proliferation [7866 \pm $1873(21.4 \%)$ vs $36598 \pm 3327(100.0 \%), p=0.0002]$.

Dynamic light scattering analyses. To evaluate whether sulphatide and insulin molecules interact, we did dynamic light scattering analyses. The mean particle diameter size for sulphatide sonicated $20 \mathrm{~s}$ was smaller when insulin was present; for sulphatide \pm insulin $(43 / 4.3 \mu \mathrm{mol} / \mathrm{l}): \quad 283 \pm 22$ vs $366 \pm 40 \mathrm{~nm}, \quad n=4$, $p=0.03$. The mass of material in aggregated form calculated on basis of the relative number of particles and particle volume, was $2.3 \pm 0.2$ times higher in the samples with sulphatide alone than in the samples with sulphatide + insulin. Hence, the fraction of sulphatide not detectable by dynamic light scanning (molecular or aggregated form less than $10 \mathrm{~nm}$ in size) was substantially enhanced when insulin was present. Vigorous vortex procedure resulted in a particle size of $103.5 \pm 3.9 \%$ of the non-vortexed samples indicating that sizes of the aggregates were unaffected by this procedure. Gal-cer + insulin solution showed an average particle size of $2794 \mathrm{~nm}$ and galcer alone $9562 \mathrm{~nm}$. In contrast, GM1 did not form detectable micelles either alone or together with insulin.

\section{Discussion}

This study has shown that sulphatide - but not its precursor (non-sulphated galactosylceramide) or another negatively charged glycolipid, GM1 - is able to inhibit insulin-induced proliferation of a specific T-cell 


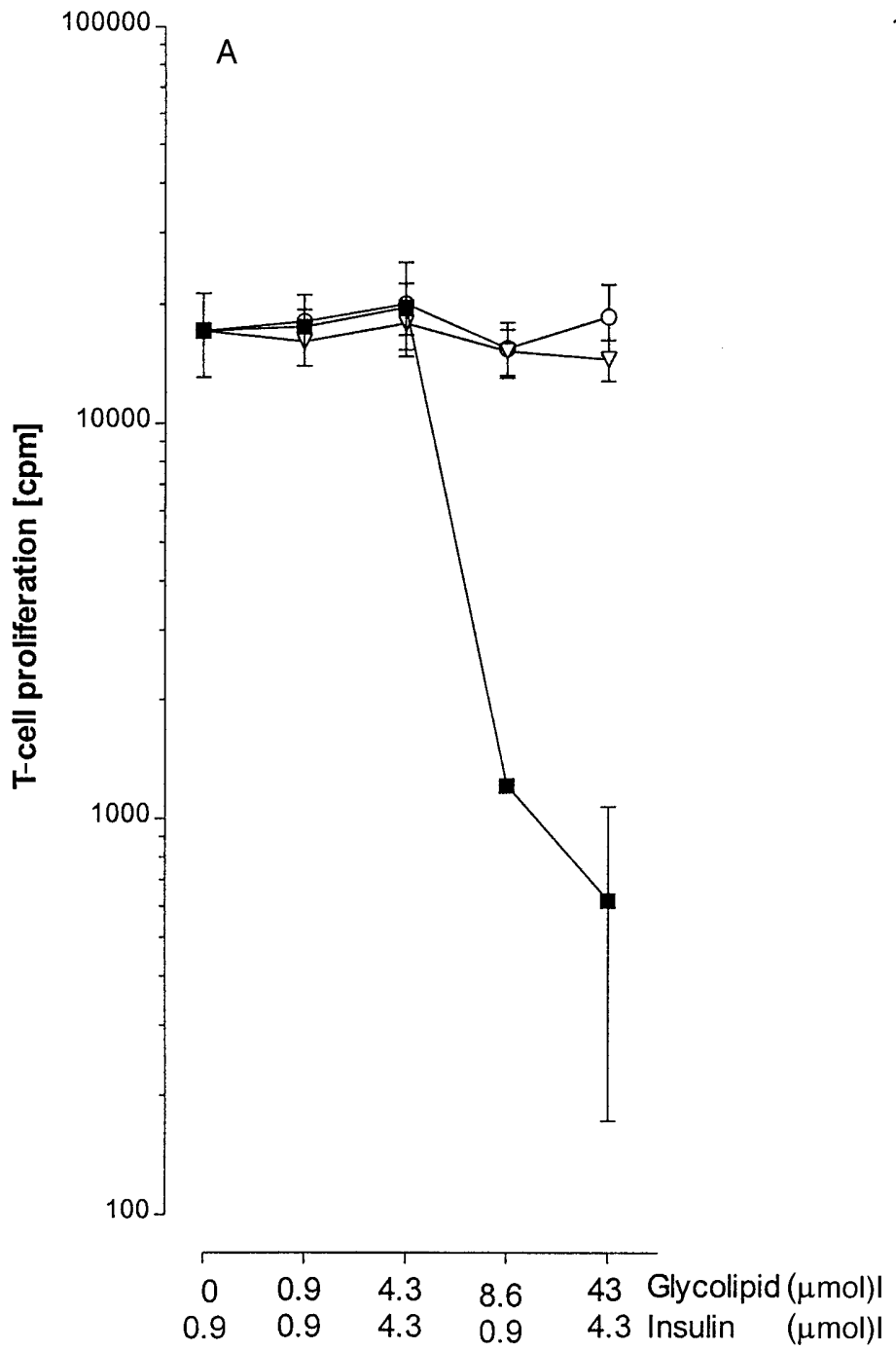

Fig. 3. A Proliferation of $\left[{ }^{3} \mathrm{H}\right]$ thymidine incorporated insulinspecific T-cells incubated with sulphatide $(\boldsymbol{\square})$, gal-cer $(\nabla)$, or GM1 $(\bigcirc)$ and insulin. Indicated are mean values $( \pm$ standard deviation) of triplicate values of a representative experiment. Each experiment was done at least three times. No inhibition of proliferation was observed of the insulin specific T-cell clone in response to IL-2. None of the glycolipids, either in the presence or absence of insulin, affected the proliferation of T-cells specific to imogen-38 or hsp65 in response to their antigen. The $\mathrm{IC}_{50}$ of insulin for the insulin-specific $\mathrm{T}$-cell clone is $1.7 \mu \mathrm{mol} / 1$ B Proliferation of $\left[{ }^{3} \mathrm{H}\right]$ thymidine incorporated insulin-specific T-cells incubated with sulphatide + insulin. The Tcells were stimulated either with insulin B-chain (B11-27) peptide $(\boldsymbol{\nabla})$ or non-specifically with PMA plus anti-CD3 $(\boldsymbol{\nabla})$. Indicated are mean values ( \pm standard deviation) of triplicate values of a representative experiment. Each experiment was done at least three times

clone in vitro. Sulphatide did not inhibit non-specific T-cell proliferation. This was confirmed using PHA stimulated primary PBMC cultures in which addition of sulphatide had no effect (data not shown). Antigen specific proliferation was affected by sulphatide to-

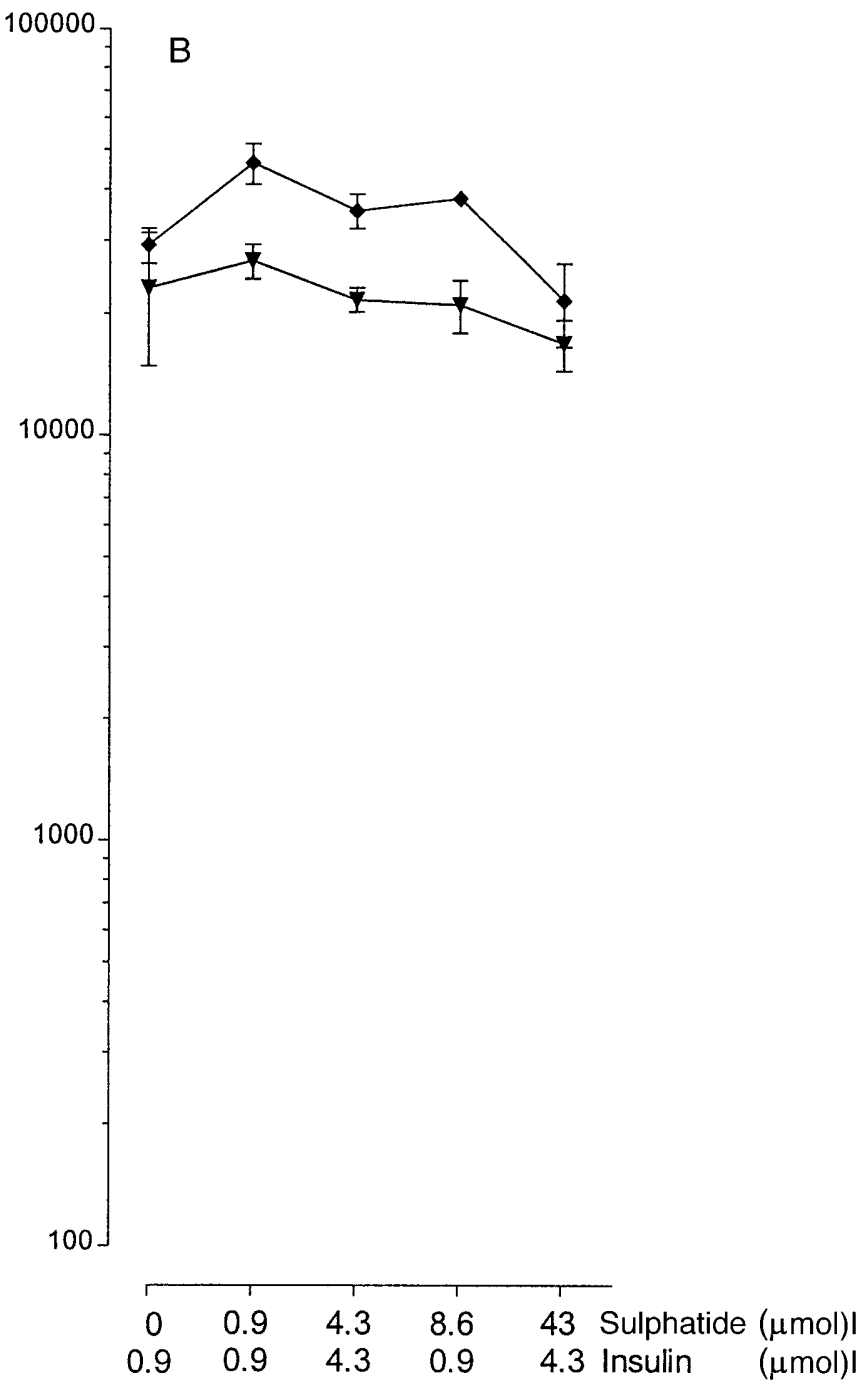

gether with insulin but not by sulphatide alone, in one T-cell clone specific to secretory granule protein, but not in two T-cell clones with different specificities (imogen-38 [22], hsp65; data not shown). Thus, a potential inhibition of proliferative response by local sulphatide-insulin aggregates in the insulitic lesion need not be limited to insulin-specific T-cell clones, but is certainly not universal. A variety of T-cell clones specific for different autoantigens have been isolated from Type I diabetic patients [26]. The apparently limited inhibitory effect of sulphatide on certain T-cell reactivities could be related to particular HLA restriction as well as the specific nature of the autoantigens that are recognized. Although there are no other insulin-specific T-cell clones at present, it would be important to validate our findings with different insulin-specific T-cell clones with different HLA restriction characteristics.

The amount of sulphatide in human pancreas is found to be $84 \mathrm{nmol} / \mathrm{g}$ pancreas which is all present in the islets [2]. Correspondingly, the insulin content is estimated to be $1.4 \mathrm{IU}$ (medium immunoreactive insulin) value of 32 human pancreases [27]) equiva- 
lent to $50 \mu \mathrm{g}$ or $8.3 \mathrm{nmol}$ per $\mathrm{g}$ pancreas, which gives an overall mol:mol relation between sulphatide and insulin of 10:1. This molar ratio, as well as an equimolar ratio, was tested in our study. Sulphatide is expressed at the surface of the islet cells at least partly due to exocytosis of the secretory granules containing sulphatide [28]. Note, insulin appears also at the outer plasma membrane of the beta cells in a dot-like fashion at the sites of exocytosis [29].

The dynamic light scattering analyses have shown that sulphatide forms aggregates of sizes up to $300-400 \mathrm{~nm}$ but to a lesser degree when insulin is present. Like insulin [30], sulphatide [3] has hydrophilic and hydrophobic regions, which is the physical explanation for its particle forming properties. We hypothesize that insulin and sulphatide interact and that attachment due to different ion charge and hydrophobic attraction is most conceivable.

The absence of an inhibitory effect of sulphatide on non-specific T-cell proliferation suggests that the suppression could be related to processing and presentation of insulin molecules. This is further supported by our data showing that the T-cell response to the peptide-epitope of insulin (B11-27), which does not require processing, was unaffected by coculture with sulphatide. Inhibition of macrophage priming has been described by sulphatide SL-I [31, 32] which, however, is structurally not identical with sulphatide (3'-sulphogalactosylceramide) used in the present study. Recently, it has been found that the phagocytosis of Staphylococcus aureus by polymorphonuclear cells and by monocytes is facilitated by coating with sulphatide [33]. Furthermore, sulphatide interfered with phagosome-lysosome fusion [33]. Uptake of sulphatide-containing liposomes of phosphatidylcholine by macrophages was statistically significantly greater than the uptake of liposomes made without sulphatide [34] whereas sulphatide inhibited the uptake of phosphatidylserine liposomes by macrophages to a level of approximately $15 \%$ of control values [34]. The interference of sulphatide with macrophages is suggested to be mediated through anionic charging modifying organelle membranes [32] or to be due to hydrophobic forces [35].

Our data suggest that sulphatide in combination with insulin is able to inhibit T-cell reaction in the local environment of the islets. This could contribute to the chronic character of islet destruction during diabetes development which often takes several years, and is consistent with the notion of persistent betacell function in some people having autoantibodies as well as T-cells directed against beta-cell autoantigens including insulin.

Several studies, both human and experimental, favour active beta cells being more vulnerable than the passive ones [14]. Among the most important indications for this concept is the hyperproduction of insulin seen in people at risk of developing diabetes
[36]. Even for NOD mice beta-cell rest is described to be of importance [37]. A finding of note in our study was that low glucose concentration upregulates the sulphatide content. In contrast, a lower sulphatide content is seen in diabetes-prone BB rats $(87 \pm 20$ pmol per 100 islets) compared with both diabetes-resistant Wistar Furth rats $(181 \pm 50 \mathrm{pmol})$ and Lewis rat islets $(410 \pm 50 \mathrm{pmol})[2]$. Note, NK-cells - present in the insulitis lesion - are described to express arylsulphatase on their surface [38] which is able to desulphate sulphatide making gal-cer. Theoretically, the presence of insulitic NK-cells can lead to ineffective modulation of T-cell autoreactivity by reduced sulphatide concentrations. Biases of NK-cells in diabetes have been reported [39].

Insulin is an important antigen in Type I diabetes. Antibodies against insulin are amongst the first antibodies seen in pre-Type I diabetes patients [40]. Furthermore, peripheral T-cell reactions directed against insulin are common in both preclinical and overt Type I diabetic patients and non-diabetic controls [41]. Our study shows that sulphatide, found together with insulin in the secretory granules and at the surface of beta cells, is capable of modifying the immunogenecity towards insulin and thereby possible influencing local T-cell autoreactivity in the microenvironment of the islets.

Acknowledgements. The study was supported by Diabetes Fonds Netherlands, Danish Diabetes Association, and Danish Medical Research Council. B. O. Roep is a fellow of the Royal Academy of Arts and Sciences, The Netherlands. The authors thank Dr E. Spierings for discussions, Professor S. Frøkjær, and Ms S. Sørensen for technical help and Professor R. de Vries and Dr F. Koning for critical reading of this manuscript.

\section{References}

1. Svennerholm L, Boström K, Fredman P, Jungkjer B, Månsson J-E, Rynmark B-M (1992) Membrane lipids of human peripheral nerve and spinal cord. Biochim Biophys Acta 1128: $1-7$

2. Buschard K, Josefsen K, Hansen SV et al. (1994) Sulphatide in islets of Langerhans and in organs affected in diabetic late complications: a study in human and animal tissue. Diabetologia 37: 1000-1006

3. Vos JP, Lopes-Cardozo M, Gadella BM (1994) Metabolic and functional aspects of sulphogalactolipids. Biochim Biophys Acta 1211: 125-149

4. Coetzee T, Fujita N, Dupree J et al. (1996) Myelination in the absence of galactocerebroside and sulfatide: normal structure with abnormal function and regional instability. Cell 86: 209-219

5. Aruffo A, Kolanus W, Walz G, Fredman P, Seed B (1991) CD62/P-selectin recognition of myeloid and tumor cell sulphatides. Cell 67: 35-44

6. Laudanna C, Constantin G, Baron P et al. (1994) Sulfatides trigger increase of cytosolic free calcium and enhanced expression of tumor necrosis factor-alfa and interleukin8 mRNA in human neutrophils. J Biol Chem 269: 4021-4026 
7. Buschard K, Diamant M, Bovin LF, Fredman P, Bendtzen K (1996) Sulphatide and ist precursor, galactosylceramide, influence the production of cytokines in human mononuclear cells. APMIS 104: 938-944

8. Fredman P, Vedeler CA, Nyland H, Aarli JA, Svennerholm L (1991) Antibodies in sera from patients with inflammatory demyelinating polyradicoloneuropathy react with the ganglioside LM1 and sulphatide of peripheral nerve myelin. J Neurol 238: 75-79

9. Ryberg B (1978) Multiple specificities of antibrain antibodies in multiple sclerosis and chronic myelopathy. J Neurol Sci 38: 357-382

10. de Gasperi R, Sosa MAG, Patarca R et al. (1996) Intrathecal synthesis of antisulphatide $\operatorname{IgG}$ is associated with peripheral nerve disease in acquired immunodeficiency syndrome. AIDS Res Hum Retroviruses 12: 205-211

11. Buschard K, Josefsen K, Horn T, Fredman P (1993) Sulphatide and sulphatide antibodies in insulin-dependent diabetes mellitus. Lancet 342: 840

12. Palmer JP, Asplin CM, Clemonts P et al. (1983) Insulin antibodies in insulin-dependent diabetes before insulin treatment. Science 222: 1337-1339

13. Naquet P, Ellis J, Tibensky D et al. (1998) T cell autoreactivity to insulin in diabetic and related non-diabetic individuals. J Immunol 140: 2569-2578

14. Buschard K (1991) The functional state of the beta cells in the pathogenesis of insulin-dependent diabetes mellitus. Autoimmunity 10: 65-70

15. Gotfredsen C, Buschard K, Frandsen E (1985) Reduction of diabetes incidence of BB Wistar rats by early prophylactic insulin treatment of diabetes-prone animals. Diabetologia 28:933-935

16. Atkinson MA, Maclaren NK, Luchetta R (1990) Insulitis and diabetes in NOD mice reduced by prophylactic insulin therapy. Diabetes 39:933-937

17. Keller RJ, Eisenbarth GS, Jackson RA (1993) Insulin prophylaxis in individuals at high risk of type 1 diabetes. Lancet 341:927-928

18. Muir A, Peck A, Clare-Salzler M et al. (1995) Insulin immunization of nonobese diabetic mice induces a protective insulitis characterized by diminished intraislet interferongamma transcription. J Clin Invest 95:628-634

19. Buschard K, Aaen K, Horn T, van Damme J, Bendtzen K (1990) Interleukin 6 is a functional and structural modulator of beta cells from islets of Langerhans. Autoimmunity 5:185-194

20. Josefsen K, Stenvang JP, Kindmark H et al. (1996) Fluorescence-activated cell sorted rat islet cells and studies of the insulin secretory process. J Endocrinology 149:145-154

21. Fredman P, Mattsson M, Andersson K et al. (1988) Characterization of the binding epitope of a monoclonal antibody to sulphatide. Biochem J 251:17-22

22. Roep BO, Arden SD, de Vries RRP, Hutton JC (1990) Tcell clones from a type-1 diabetes patient respond to insulin secretory granule proteins. Nature 345:632-634

23. Schloot NC, Willemen S, Duinkerken G, de Vries RRP, Roep BO (1998) Cloned T cells from a recent onset IDDM patient reactive with insulin B-chain. J Autoimmun 11:169-175

24. Svennerholm L, Fredman P (1980) A procedure for the quantitative isolation of brain ganglioside. Biochim Biophys Acta 617:97-109
25. Månsson J-E, Mo H, Egge H, Svennerholm L (1986) Trisialosyllactosylceramide (GT3) is a ganglioside of human lung. FEBS Lett 196:259-262

26. Roep BO (1996) T-cell responses to autoantigens in IDDM. The search for the holy grail. Diabetes 45: 1147-1156

27. Rastogi GK, Sinha MK, Dash RJ (1973) Insulin and proinsulin content of pancreases from diabetic and nondiabetic subjects. Diabetes 22:804-807

28. Buschard K, Josefsen K, Rygaard J, Spitalnik SL (1991) Pancreatic islet cell epitope recognized by an anti-sulphatide monoclonal antibody. APMIS 99:1151-1156

29. Larsson L-I, Nielsen JH, Hutton JC, Madsen OD (1989) Pancreatic hormones are expressed on the surfaces of human and rat islet cells through exocytotic sites. J Cell Biol 48:45-51

30. Brange J (1994) Stability of insulin. Kluwer Academic Publishers, Dordrecht

31. Pabst MJ, Gross JN, Brozna JP, Goren MB (1988) Inhibition of macrophage priming by sulphatide from Mycobacterium tuberculosis. J Immunol 140:634-640

32. Goren MB, Hart PD, Young MR, Armstrong JA (1976) Prevention of phagosome-lysosome fusion in cultured macrophages by sulphatides of Mycobacterium tuberculosis. Proc Natl Acad Sci USA 73: 2510-2514

33. Yamaguchi S, Miyazaki Y, Oka S, Yano I (1996) Stimulation of phagocytosis and phagosome-lysosome (P-L) fusion of human polymorphonuclear leukocytes by sulfatide (Galactosylceramide-3-sulfate). FEMS Immunol Med Microbiol 13: 107-111

34. Greenspan P, Gutman RL (1994) Endocytosis of sulphatides by macrophages: relationship to the cellular uptake of phosphatidylserine. J Leukoc Biol 55: 99-104

35. de Chastellier C, Thilo L (1997) Phagosome maturation and fusion with lysosomes in relation to surface property and size of the phagocytic particle. Eur J Cell Biol 74:49-62

36. Hollander PH, Asplin CM, Kniaz D, Hansen JA, Palmer JP (1982) Beta cell dysfunction in nondiabetic HLA identical siblings of insulin-dependent diabetics. Diabetes 31:149-153

37. Bowman MA, Campbell L, Darrow BL, Ellis TM, Suresh A, Atkinson MA (1996) Immunological and metabolic effects of prophylactic insulin therapy in the NOD-scid/scid adoptive transfer model of IDDM. Diabetes 42: 205-208

38. Zucker-Franklin D, Grusky G, Yang J-S (1983) Arylsulfatase in natural killer cells: Its possible role in cytotoxicity. Proc Natl Acad Sci USA 80: 6977-6981

39. Wilson SB, Kent SC, Patton KT et al. (1998) Extreme Th1 bias of invariant Valpha24alphaQ T cells in type 1 diabetes. Nature 391:177-181

40. Atkinson MA, Maclaren NK (1994) The pathogenesis of insulin-dependent diabetes mellitus. N Engl J Med 331: 1428-1436

41. Schloot NC, Roep BO, Wegmann D et al. (1997) Altered immune response to insulin in newly diagnosed compared to insulin-treated diabetic patients and healthy control subjects. Diabetologia 40:564-572 